\title{
Pengaruh Pemberian Jus Sambung Nyawa (Gynura procumbens L. merr) Terhadap Produksi Ayam Pedaging
}

\author{
Nata Dian Nanda ${ }^{1}$ ), Edya Moelia Moeis ${ }^{2}$ ) dan Eddy Trijana Sudani ${ }^{2}$ ) \\ 1) Mahasiswa Program Studi Ilmu Ternak Fakultas Peternakan \\ ${ }^{2)}$ Dosen Program Studi Ilmu Ternak Fakultas Peternakan
}

\author{
Universitas Islam Balitar \\ Jl. Majapahit No. 04 Kota Blitar
}

\begin{abstract}
The objective of this study was to determine the effect off sambung nyawa (Gynura procumbens) juice in drinking water on broiler performance (feed consumption, aver-ege daily gain, feed conversion and persentasion carcass). The research is used 200 broiler Hybro strains from PT. Manggis, were allocated into 4 treatments and 5 replications consisting of 10 broiler. Maintenance of the chicken is done for 28 days. The treatment was juice sambung nyawa with each concentration : T0 (without the addition of sambung nyawa juice), T1 (addition of 10 sambung nyawa juice in $1000 \mathrm{ml}$ of drinking water), T2 (addition of 20 sambung nyawa juice in $1000 \mathrm{ml}$ of drinking water) and T3 (addition of 30 sambung nyawa juice in $1000 \mathrm{ml}$ of drinking water). Parameters observed in this study is broiler performance (feed consumption, aver-ege daily gain, feed conversion and persentasion carcass). The result from a completely randomized design were analyzed using ANOVA (Analysis of Variance / ANOVA) and if significant difference test followed by Duncan continued. The result showed that the addition of sambung nyawa juice at different levels $(10,20$ and $30 \mathrm{ml})$ in the drinking water of broilers was highly did not affect $(\mathrm{P}>0.05)$ on broiler performance (feed consumption, aver-ege daily gain, feed conversion and persentasion carcass).
\end{abstract}

Keyword : Sambung Nyawa Juice, Performance Broiler.

\section{Pendahuluan}

Perkembangan peternakan dewasa ini menunjukkan hasil yang sangat pesat demikian halnya dengan peternakan unggas salah satunya adalah ayam pedaging. Populasi ternak ayam pedaging dari tahun ketahun mengalami peningkatan, hal ini dapat dilihat dari tahun 2014 sampai 2016 dengan populasi sebanyak 12.692.213 ekor pada tahun 2014, populasi sebanyak 12.903.759 pada tahun 2015 dan populasi meningkat sebanyak 15.283.290 ekor pada tahun 2016 (Dirjen Peternakan dan Keswan, 2017). Data di atas menunjukkan bahwa dalam rentan waktu tiga tahun terakhir terjadi peningkatan yang signifikan usaha peternakan ayam pedaging di Indonesia.

Keberhasilan usaha peternakan ayam pedaging di tentukan oleh tiga aspek penting yaitu pembibitan, pakan dan tata laksana ( manajemen ) yang baik. Salah satu keberhasilan tersebut di ukur dengan tingkat keuntungan yang di diperoleh secara maksimal. Namun jika dilihat dari biaya produksi dalam usaha peternakan, kontribusi pakan adalah yang paling tinggi yaitu sekitar $70 \%$ dari total biaya produksi. Pakan yang berkualitas mengandung zatzat makanan dalam jumlah cukup dan seimbang sangat dibutuhkan ternak untuk menghasilkan produksi yang optimal. Agar terjadi peningkatan produksi ternak yang optimal dilakukan melalui perbaikan kualitas pakan dan efisiensi penggunaan pakan. Salah satu cara 
yang dapat dilakukan untuk meningkatkan efisien penggunaan pakan pada ayam pedaging adalah dengan penambahan feed additive dalam pakan dan air minum.

Nuraini, 2012 (dalam Sulistyoningsih, dkk, 2014) menyatakan bahwa banyak jenis tanaman yang terdapat di Indonesia yang mempunyai potensi untuk dijadikan sebagai feed additive. Tanaman Sambung Nyawa merupakan salah satu tanaman herbal yang dijumpai dan dimanfaatkan oleh masyarakat Indonesia. Masyarakat Indonesia menggunakan tanaman Sambung Nyawa sebagai pelengkap makanan (lalapan) dan juga sebagai obat-obatan manusia seperti sebagai obat penyakit ginjal, infeksi kerongkongan, menghentikan pendarahan, dan penawar racun akibat gigitan binatang berbisa dan masih banyak yang lainnya.

Sambung Nyawa merupakan tanaman yang tumbuh merambat dengan karakteristik daun tunggal, berbentuk oval, dan memiliki rambut halus pada permukaan atas bawah daunnya (Fadli, 2015). Tanaman Sambung Nyawa merupakan tanaman yang diduga berasal dari daratan Cina, tetapi penyebaran di Indonesia sudah sampai hampir di seluruh wilayah Nusantara (Nurwahyuni, 2006). Fadli (2015) menyatakan bahwa tanaman Sambung Nyawa sering digunakan sebagai obat maupun makanan untuk kesehatan manusia, dapat berupa lalapan maupun berupa kapsul atau teh. Jenis tanaman yang memiliki fleksibilitas tinggi dalam hal adaptasi dan memiliki khasiat yang beragam. Oleh karena itu pada saat ini banyak yang menanam sambung nyawa sebagai tanaman obat keluarga.

Menurut Abdurrahman (2007) Sambung Nyawa memiliki sifat hipotensif atau menurunkan tekanan darah, hipoglikaemik atau menurunkan kadar gula darah, mencegah dan meluruhkan batu ginjal dan batu kandung kemih, antihiperlipidemia atau menurunkan kolesterol dan trigliserida, antibakteri atau membunuh dan mencegah pembiakan bakteri, sitostatik atau menghambat pertumbuhan sel kanker, mencegah dan memperbaiki kerusakan sel-sel jaringan ginjal dan tidak toksik sehingga aman digunakan sebagai obat maupun makanan tambahan. Fadli (2015) menyatakan kandungan Flavonoid, Triterpen, Poliferol, Sterol tak jenuh, Minyak Atsiri, Asam P-hidroksi Benzoat, Saponin, Tanin dan Asam klorogenat dalam Sambung Nyawa merupakan bahan yang digunakan dalam campuran obat maupun terapi. Sebagai alternatif, penggunaan Sambung Nyawa dapat digunakan sebagai feed additive. Menurut Wijayanti (2012) komposisi daun Sambung Nyawa dalam ekstrak yang larut dalam etanol 95\% antara lain Asam Klorogenat, Asam Kaveat, Asam Vanilat, Asam Kumarat, Asam Hidroksi Benzonat. Hasil dari analisa kualitatif dengan metode kromatografi skrining Fitokimia dapat dideteksi keberadaan kandungan Flavonoid, Tannin, Saponin, Alkanoid, Triterpenoid (Balai Material Medica, 2017) dan mengadung Minyak Atsiri (Wijayanti, 2012).

Abdurrahman (2007) menyatakan daun Sambung Nyawa secara umum mengandung Minyak Atsiri 0,05\%. Daun Sambung Nyawa memiliki daya anti bakteri terhadap beberapa bakteri pantogen. Widyaningrum (2015) menyatakan bahwa pemakaian daun Sambung Nyawa untuk obat disebabkan adanya kandungan Flavonoid dan Minyak Atsiri yang dikandungnya. Bahan kimia yang terkandung di dalam daun Sambung Nyawa yang berperan sebagai aktifitas sistem imun adalah Flavonoid (Katekin 70\%). Tannin yang merupakan senyawa Polifenol yang mampu mencegah stres oksidatif (Wiratmi, 2014).

Berdasarkan pada kandungan zat aktif yang dimiliki oleh Sambung Nyawa dan terbatasnya informasi tentang pemanfaatannya dalam bidang peternakan maka perlu dilakuan penelitian penambahan jus daun Sambung Nyawa untuk menguji kemampuannya dalam meningkatkan penampilan produksi ayam pedaging khusunya dalam efisiensi penggunaan 
pakan. Efisiensi penggunaan pakan dapat dilihat dari penampilan ayam pedaging yaitu pertambahan bobot badan, konsumsi pakan, konversi pakan, bobot badan akhir, serta yang lebih penting persentase bobot karkas yang bisa dihasilkan dari jumlah konsumsi pakan tersebut. Oleh karena itu penelitian ini dilakukan untuk mengkaji pengaruh pemberian jus sambung nyawa terhadap produksi ayam pedaging.

Tujuan dari penelitian ini adalah mengetahui tingkat pemberian jus Sambung Nyawa terhadap produksi pada ayam pedaging.

\section{Metode Penelitian}

Penelitian ini menggunakan Day Old Chick (DOC) ayam pedaging srain Hybro dari PT. Manggis. Ayam pedaging yang digunakan sebanyak 200 ekor dengan pakan yang digunakan merupakan pakan basal buatan pabrik. Kandang yang digunakan selama penelitian adalah kandang box untuk pemeliharaan ayam pedaging umur $1-14$ hari, selanjutnya menggunakan kandang panggung dengan ukuran 4 x 5 meter yang diberi sekat ukuran $100 \mathrm{x}$ $100 \mathrm{~cm}$ sebanyak 20 buah, yang berisi sepuluh ekor untuk pemeliharaan ayam broiler umur 14 sampai 28 hari. Masing-masing kandang dilengkapi tempat pakan dan tempat minum. Peralatan yang digunakan dalam penelitian ini adalah timbangan digital skala 1 gram untuk menimbang pakan dan ternak, gelas ukur, blender serta pisau.

Pada penelitian ini menggunakan daun Sambung nyawa yang diperoleh dari UPT. Balai Material Medica, Batu, Malang. Pakan yang digunakan dalam penelitian ini menggunakan Pakan Jadi 201C yang di produksi oleh PT. Gold Coin Indonesia untuk pemeliharaan ayam pedaging pada umur 1-28 hari.

Penelitian ini berdasarkan metode experimental dengan menggunakan Rancangan Acak Lengkap (RAL), yang menggunakan 4 perlakuan dengan 5 kali ulangan yang masing-masing ulangan terdiri 10 ekor ayam. Perlakuan yang digunakan dalam penelitian adalah sebagai berikut :

$\mathrm{P} 0: 1000 \mathrm{ml}$ air minum tanpa penambahan.

P1 : $1000 \mathrm{ml}$ air minum $+10 \mathrm{ml}$ jus daun Sambung Nyawa.

P2 : $1000 \mathrm{ml}$ air minum $+20 \mathrm{ml}$ jus daun Sambung Nyawa.

P3 : $1000 \mathrm{ml}$ air minum $+30 \mathrm{ml}$ jus daun Sambung Nyawa.

Penambahan jus daun Sambung Nyawa pada air minum dilakukan dengan cara dicampurkan setiap $1000 \mathrm{ml}$. Ukuran pemberian jus daun Sambung Nyawa di sesuaikan dengan tingkat perlakuan dan di campur dengan air minum dan dilakukan pada pagi hari pukul 07.00 WIB. Perlakuan penambahan jus daun Sambung Nyawa pada air minum dilaksanakan pada ayam pedaging berumur 14 hari sampai 28 hari. Proses pembuatan jus daun Sambung Nyawa di mulai dengan menimbang daun Sambung Nyawa segar 100 gram kemudian di cuci bersih, selanjutnya ditambahkan $100 \mathrm{ml}$ aquades kemudian di blender selama 15 menit, selanjutnya di campurkan pada air minum sesuai dengan tingkat perlakuan.

Data yang diperoleh di analisis dengan sidik ragam Analysis of Variance ( ANOVA ) apabila terjadi pengaruh yang nyata atau sangat nyata maka dilanjutkan dengan Uji Duncan.

Model matematika dalam analis data seperti di bawah :

$$
\text { Yij } \quad=\mu+\alpha i+\varepsilon i j
$$


Keterangan :

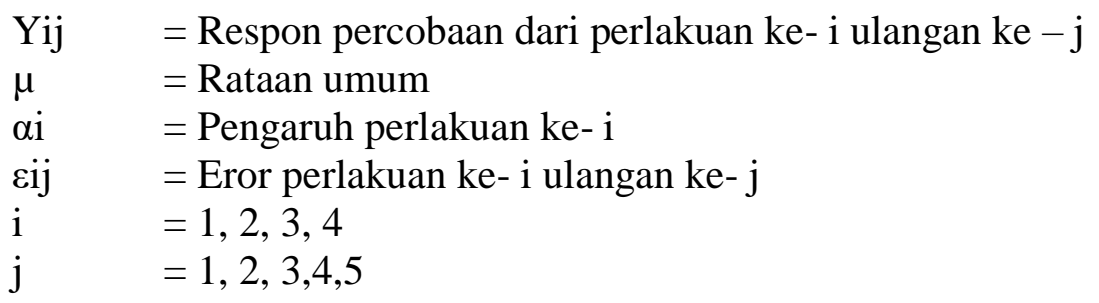

\section{Hasil Dan Pembahasan}

\section{Konsumsi Pakan}

Hasil Analisis Sidik Ragam menunjukkan bahwa pemberian jus Sambung Nyawa pada $1000 \mathrm{ml}$ air minum tidak berpengaruh nyata $(\mathrm{P}>0,05$ ) terhadap konsumsi pakan ayam pedaging. Konsumsi pakan yang tidak berbeda dalam penelitian ini, kemungkinan karena pemberian Sambung Nyawa dalam bentuk jus sampai tingkat $30 \mathrm{ml}$ dalam $1000 \mathrm{ml}$ air minum masih bisa ditolerir untuk dikonsumsi ayam. Hal ini kemungkinan juga disebabkan kandungan nutrisi pakan tersebut mempunyai kandungan protein dan energi yang sama sehingga tidak berpengaruh terhadap konsumsi pakan dikarenakan semua pelakuan diberikan pakan yang sama. Hal ini sesuai menurut Nuningtyas (2014) bahwa konsumsi pakan ayam pedaging dipengaruhi oleh kandungan zat makanan dalam pakan. Konsumsi pakan ternak sangat dipengaruhi oleh jenis kelamin, besarnya tubuh, keaktifan dan kegiatan pertumbuhan atau produktivitas lainnya dan faktor lingkungan yaitu suhu dan kelembaban udara (Wulandaputri, 2012).

Hal ini juga menunjukkan bahwa perlakuan pemberian jus Sambung Nyawa tidak mempengaruhi rata-rata konsumsi pakan, akan tetapi secara numerik rata-rata konsumsi pakan pada ayam pedaging yang mendapat perlakuan P3 lebih rendah dari P0. Pemberian jus Sambung Nyawa yang mengandung zat - zat fitokimia berupa flavonoid dan minyak atsiri tidak memberikan pengaruh yang nyata pada perlakuan P3 terhadap konsumsi pakan. Hasil penelitian yang dilakukan Nurhayati dan Handoko (2011) menunjukkan bahwa penggunaan tepung gulma (bandotan, patikan kebo dan sidaguri) yang mengandung flavonoid dalam pakan dan sebagai bahan pakan tambahan dalam pakan ayam pedaging dengan level penambahan 5\% tidak mempengaruhi konsumsi pakan akan tetapi tidak diketahui berapa persentasi flavonoid yang terkandung.

Walaupun secara statistik tidak berbeda nyata, secara numerik terjadi penurunan konsumsi ransum. Rendahnya konsumsi pakan pada P3 $=3 \%$ diduga disebabkan pemberian jus Sambung Nyawa pada air minum mempengaruhi konsumsi pakan, bau yang khas dan agak sedikit langir pada daun Sambung Nyawa sehingga dapat menurunkan palatabilitas. Palabilitas ternak dipengaruhi oleh beberapa faktor yang mempengaruhinya yaitu rasa, bau dan warna dari bahan pakan (Pond et al., 1995 dalam Sugiarto, 2008).

\section{Pertambahan Bobot Badan}

Hasil Analisis Sidik Ragam menunjukkan bahwa pemberian jus Sambung Nyawa pada $1000 \mathrm{ml}$ air minum tidak berpengaruh nyata $(\mathrm{P}>0,05)$ terhadap pertambahan bobot badan ayam pedaging. Tidak adanya perbedaan pengaruh yang nyata diduga disebabkan kandungan nutrisi pakan terutama energi dan protein yang terkandung dalam pakan yang diberikan 
selama penelitian sama, karena menggunakan pakan komersial. Kondisi tersebut menyebabkan rataan dari analisa sidik ragam pertambahan bobot badan yang tidak berbeda. Hal ini didukung oleh Sugiarto (2008), bahwa ransum yang mengandung protein lebih tinggi dari lainnya cenderung memberikan pertambahan bobot badan yang lebih tinggi. Serta menurut Sjofjan (2008) bahwa kandungan nutrisi makanan ternak terutama energi dan protein dalam pakan yang diberikan hampir sama akan menghasilkan pertambahan bobot hidup yang relatif sama.

Pemberian jus Sambung Nyawa pada air minum yang diharapkan dapat meningkatkan nafsu makan, namun secara statistik tidak memberikan pengaruh yang nyata sehingga menghasilkan pertambahan bobot badan yang tidak nyata. Selain itu keberadaan zat fitokimia dalam jus sambung nyawa berupa senyawa flavonoid dan minyak atsiri dalam perlakuan pemberian jus Sambung Nyawa belum mampu mempengaruhi secara analisis sidik ragam konsumsi pakan sehingga berdampak pada penurunan pertambahan bobot badan. Hal ini sesuia menurut Rasyaf (2008) bahwa pertambahan berat badan ayam pedaging dipengaruhi oleh jumlah ransum yang dikonsumsi dan kandungan nutrisi ransum.

\section{Konversi Ransum}

Hasil Analisis Sidik Ragam menunjukkan bahwa pemberian jus Sambung Nyawa pada $1000 \mathrm{ml}$ air minum tidak berpengaruh nyata $(\mathrm{P}>0,05$ ) terhadap konversi ransum ayam pedaging. Hal ini diduga disebabkan pemberian Sambung Nyawa dalam bentuk jus tidak berpengaruh nyata terhadap konsumsi pakan dan pertambahan bobot badan ayam pedaging, sehingga akan mempengaruhi angka konversi ransum ayam pedaging. Menurut Wahju, 2004 (dalam Wulandaputri, 2012) bahwa konversi ransum merupakan jumlah ransum yang dibutuhkan oleh ternak untuk menghasilkan suatu unit pertambahan bobot badan dalam waktu tertentu, semakin besar ukuran dan tua umur ternak maka nilai konversinya akan semakin tinggi. Efisiensi penggunaan pakan dipengaruhi oleh konsumsi pakan dan pertambahan bobot badan, apabila konsumsi pakan yang minimum menghasilkan pertambahan bobot badan yang minimum, maka efisiensi penggunaan pakan akan tinggi (Widjastuti dan Sujana, 2009).

\section{Persentase Karkas}

Hasil Analisis Sidik Ragam menunjukkan bahwa pemberian jus Sambung Nyawa pada $1000 \mathrm{ml}$ air minum tidak berpengaruh nyata $(\mathrm{P}>0,05)$ terhadap persentase karkas ayam pedaging. Tidak adanya perbedaan pengaruh yang nyata terhadap persentase karkas diduga disebabkan peberian jus Sambung Nyawa dalam air minum tidak mempengaruhi terhadap pertambahan bobot badan ayam sehingga berpengaruh pada pembentukan daging, dengan demikian pemberian jus Sambung Nyawa dalam air minum belum mampu meningkatkan persentase karkas ayam pedaging secara nyata. Kondisi tersebut menyebabkan rataan dari analisa sidik ragam persentase karkas yang tidak berbeda. Hal ini sesuai pendapat Saputra (2015) bahwa pencapaian bobot karkas sangat berkaitan dengan bobot hidup dan pertambahan bobot badan. Bobot karkas dipengaruhi dengan bobot hidup, sehingga bobot hidup yang besar akan diikuti pula oleh bobot karkas yang besar pula, dan sebaliknya (Zura, dkk, 2012).

Walaupun secara statistik tidak berbeda nyata, namun secara numerik terjadi peningkatan angka persentase karkas. Peningkatan angka persentase karkas pada perlakuan diduga dipengaruhi peningkatan bobot badan secara numerik sehingga mempengaruhi angka 
persentase karkas. Soeparno,1994 (dalam Lingga, dkk, 2016) karkas erat hubungannya dengan berat badan, apabila berat badan meningkat, karkas juga ikut meningkat. Perbedaan hasil dalam penelitian ini, kemungkinan juga disebabkan oleh perbedaan jenis kelamin setiap sampel yang diambil dari setiap unit percobaan tidak dipisah antara jantan dan betina. Hal ini sesuai pendapat Mangelep (2017) bahwa faktor-faktor yang dapat mempengaruhi bobot karkas antara lain umur, jenis kelamin, dan bobot badan bobot potong, besar dan konformasi tubuh, perlemakan, kualitas dan kuantitas ransum serta strain yang dipelihara.

\section{Kesimpulan}

Berdasarkan penelitian ini dapat disimpulkan bahwa pemberian jus sambung nyawa dengan tingkat 10, 20 dan $30 \mathrm{ml}$ pada $1000 \mathrm{ml}$ air minum tidak berpengaruh nyata terhadap peningkatan produksi ayam pedaging pada umur 14 - 28 hari, yang meliputi konsumsi pakan, pertambahan bobot badan, konversi pakan dan persentase karkas.

\section{Daftar Pustaka}

Abdurrahman, K. 2007. Efek Ekstrak Daun Sambung Nyawa Terhadap Kualitas Sperma Tikus Diabetik Akibat Induksi Streptozotocin. Skripsi. Fakultas MIPA. Universitas Negeri Semarang.

Akbar, A. 2009. Evaluasi Nutrisi Ransum Ayam Broiler Di CV. Pandu Putra Mandiri Desa Cibolang Kecamatan Karang Tengah Kabupaten Sukabumi. Universitas Diponegoro. Semarang.

Azizah, E, M. 2013. Pengaruh Penggunaan Tepung Serai Wangi (Cymbopogon Nardus) Dalam Pakan Terhadap Penampilan Produksi Ayam Pedaging. Jurnal. Fakultas Peternakan. Unuversitas Brawijaya. Malang.

Direktorat Jenderal Peternakan dan Kesehatan Hewan. 2017. Populasi Dan Produksi Peternakan Di Indonesia. Di Akses tanggal 22 januari 2017.

Fadli, M, Y. 2015. Benefits Of Sambung Nyawa (Gynura Procumbens) Subtance As Anticancer. Jurnal. Faculty of Medicine, Lampung University.

Lingga, H, dkk. 2016. Pengaruh Pemberian Ekstrak Daun Bandotan (Ageratum Conyzoides) Terhadap Berat Karkas Dan Lemak Abdominal Ayam Broiler. Fakultas Kedokteran Hewan. Universitas Syiah Kuala, Banda Aceh.

Manurung, E, J. 2011. Performa ayam broiler pada frekuensi dan waktu pemberian pakan yang berbeda. Skripsi. Fakultas Peternakan. Insitut Pertanian Bogor.

Margi, D dan W, Hermana. 2012. Pakan Ayam. Penebar Swadaya. Jakarta.

Nuningtyas, Y, F. 2014. Pengaruh Penambahan Tepung Bawang Putih (Allium Sativum) Sebagai Aditif Terhadap Penampilan Produksi Ayam Pedaging. Jurnal. Fakultas Peternakan. Umiversitas Brawijaya Malang.

Nurhayati, N dan Handoko, H. 2011. Pemberian Gulma Berkhasiat Obat dalam Ransum terhadap Penampilan Ayam Pedaging. Fakultas Peternakan Universitas Jambi. Jambi. 
Nurwahyunani, A. 2006. Efek Ekstrak Daun Sambung Nyawa Terhadap Kadar Kolesterol Ldl Dan Kolesterol Hdl Darah Tikus Diabetik Akibat Induksi Streptozotocin. Skripsi. Fakultas MIPA. Universitas Negeri Semarang.

Rasyaf, M. 2008. Paduan Berternak Ayam Pedaging. Penebar Swadaya. Jakarta

Santoso dan Sudaryani. 2011. Pembesaran Ayam Pedaging. Penebar Swadaya. Jakarta.

Sjofjan, O. 2008. Efek Penggunaan Tepung Daun Kelor (Moringa Oleifera) Dalam Pakan Terhadap Penampilan Produksi Ayam Pedaging. Fakultas Peternakan Universitas Brawijaya. Malang

Sugiarto, B. 2008. Performa Ayam Broiler Dengan Pakan Komersial Yang Mengandung Tepung Kemangi (Ocimum Basilicum). Skripsi. Fakultas Peternakan. Insitut Pertanian Bogor.

Sulistyoningsih, M., M. A. Dzaky dan A. Nurwahyuani. 2014. Optimalisasi Feed Additive Herbal Terhadap Bobot Badan, Lemak Abdominal Dan Glukosa Darah Ayam Broiler. Fakultas MIPA. Universitas PGRI Semarang.

Sumarsono, H, P. 2008. Pengaruh Penggunaan Tepung Daun Sembung (Blumea Balsamifera) Dalam Ransum Terhadap Performa Ayam Broiler. Skripsi. Fakultas Peternakan. Insitut Pertanian Bogor.

Suprijatna, S., U. Atmomarsono dan R. Kartasudjana . 2008. Dasar Ilmu Ternak Unggas. Penebar Swadaya. Jakarta.

Ulfa, M. 2008. Efek Hepatoprotektif Ekstrak Etil Asetat Daun Sambung Nyawa (Gynura Procumbens (Lour.) Dc.) Terhadap Mencit Jantan Galur Swiss Terinduksi Parasetamol. Skripsi. Fakultas Farmasi. Universitas Muhammadiyah Surakarta.

Widyaningrum, A. 2015. Pengaruh Perasan Daun Sambung Nyawa (Gynura Procumbens (Lour) Merr.) Tewrhadap Kadar Kolestrol Mencit (Mus Musculus L) Dan Pemanfaatannya Sebagai Karya Ilmiah Populer. Skripsi. Fakultas Keguruan Dan Ilmu Pedidikan. Universitas Jember.

Widyawati, W. 2007. Efek Ekstrak Daun Sambung Nyawa (Gynura Procumbens (Lour) Merr.) Terhadap Kadar Metil Merkuri Darah Dan Karakteristik Eritrosit Tikus Putih (Rattus Norvegicus L.) Paska Pemaparan Metil Merkuri Klorida. Skripsi. Fakultas MIPA. Universitas Sebelas Maret. Surakarta.

Wijayanti, R. 2012. Budidaya Sambung Nyawa (Gynura Procumbens (Lour.) M) Dan Khasiatnya Di PT. Indmira. Fakultas pertanian. Universitas Sebelas Maret. Surakarta.

Wulandaputri, A. 2012. Pengaruh penambahan biji ketumbar (Coriander sativum Linn) dalam ransum terhadap performa ayam broiler di daerah tropis. Skripsi. Fakultas Peternakan. Insitut Pertanian Bogor. 